\title{
ANTIBIOTIC CONSUMPTION IN HOSPITALS AND RESISTANCE RATE OF KLEBSIELLA PNEUMONLAE AND ESCHERICHLA COLI IN MONTENEGRO
}

\author{
Gordana Mijović1,2, Lidija Čizmović3 ${ }^{3}$, Mirjana Nedović Vuković ${ }^{1,2}$, \\ Siniša Stamatovićc ${ }^{4}$ and Milena Lopičić ${ }^{1}$ \\ ${ }^{1}$ Institute of Public Health of Montenegro, Podgorica, Montenegro; \\ ${ }^{2}$ Faculty of Medicine, University of Montenegro, Podgorica, Montenegro; \\ ${ }^{3}$ Agency for Medicines and Medical Devices of Montenegro, Podgorica, Montenegro; \\ ${ }^{4}$ Faculty of Science and Mathematics, University of Montenegro, Podgorica, Montenegro
}

\begin{abstract}
SUMMARY - Inappropriate use of antibiotics leads to an increase in antibiotic resistance. Infections caused by antibiotic-resistant gram-negative bacteria are a serious threat to public health. This study aimed to compare data on inpatient antibiotic consumption with antimicrobial resistance (AMR) rate of Klebsiella pneumoniae and Escherichia coli invasive strains in Montenegro and provide targets for improving antibiotic use. We used the national data on antibiotic consumption from 2009 to 2015, Point Prevalence Survey data on inpatient antibiotic consumption from 2015, and national AMR data on 79 Klebsiella pneumoniae and 68 Escherichia coli isolates collected from 8 hospitals from 2016 to 2018. The most commonly used antibiotics were third-generation cephalosporins with a median annual consumption of $0.66 \mathrm{DDD} / 1000 /$ day. Ceftriaxone was the most frequently prescribed antibiotic in the treatment of community/hospital acquired infections and surgical/medical prophylaxis. The highest resistance rates were recorded for Klebsiella pneumoniae to ceftriaxone, ceftazidime and gentamicin (93.59\%, 90.79\% and 89.87\%, respectively), and Escherichia coli to aminopenicillins, ceftriaxone and ceftazidime $(89.06 \%, 70.15 \%$ and $61.54 \%$, respectively). High consumption of broadspectrum antibiotics in Montenegro is accompanied by the high rate of resistance of Klebsiella pneumoniae and Escherichia coli to these agents. Antibiotic misuse demands the introduction of an antimicrobial stewardship program in Montenegrin hospitals.
\end{abstract}

Key words: Antibiotics, consumption; Antibiotics, resistance; Klebsiella pneumoniae; Escherichia coli; Montenegro

\section{Introduction}

Antibiotic resistance has emerged as one of the major global public health problems of the $21^{\text {st }}$ centu$\mathrm{ry}^{1}$. Resistance develops more rapidly through the misuse and overuse of antibiotics due to a selective antibiotic pressure ${ }^{2}$. Antibiotic consumption and resistance data provide crucial information necessary to make the

Correspondence to: Assoc. Prof. Gordana Mijović, $M D, P h D$, Institute of Public Health of Montenegro, Džona Džeksona bb, 81000, Podgorica

E-mail: gordana.mijovic@ijzcg.me

Received July 22, 2019, accepted April 21, 2020 right decisions and create effective activities to improve the proper use of antibiotics ${ }^{3,4}$.

The majority of antibiotics are used in the community, yet the proportion of patients in hospitals who receive antibiotics is significantly higher due to their usage for prophylactic and therapeutic purposes. Due to immunocompromised conditions, use of medical devices, invasive and complex procedures, patients admitted with severe infections, and healthcare-associated infections, hospitals are places with continuous selective pressure of antibiotics, and hence also places where new resistance mechanisms are first generated ${ }^{5}$. 
While resistance of gram-positive bacteria has been generally stable or decreasing, resistance in gramnegative bacteria has increased worldwide ${ }^{6-8}$. Infections due to antibiotic-resistant gram-negative bacteria are a particularly severe threat to public health because they are challenging to treat, and unquestionably they have substantial effects on morbidity, mortality, and significant healthcare expenses ${ }^{9}$.

Escherichia coli (E. coli) and Klebsiella pneumoniae (K. pneumoniae) are among the most important gramnegative pathogens the susceptibility of which to antibiotics has been monitored according to the recommendations of the World Health Organization (WHO) and European Center for Disease Prevention and Control (ECDC) $)^{10,11}$.

This study aimed to compare data on antibiotic consumption in hospitals with antimicrobial resistance rate (AMR) of E. coli and $K$. pneumoniae invasive strains in Montenegro and provide targets for improving antibiotic use.

\section{Methods}

In this study, we used three sources of data, i.e. data on antibiotic consumption in hospitals from the Montenegro Agency for Medicines and Medical Devices (CALIMS) from 2009 to 2015; Point Prevalence Survey (PPS) on antibiotic consumption in Montenegrin hospitals in 2015; and Institute of Public Health national data on AMR for the 2016-2018 period.

Bearing in mind that antibiotic resistance is the result of years of misuse of antibiotics, we used data on antibiotic consumption in hospitals for the period preceding the start of resistance data collection, which means for the 2009-2015 period. CALIMS collects data on drug turnover during the calendar year from all wholesalers with marketing authorization for medicines. Data are processed according to the WHO recommendations and using the methodology for consumption monitoring by the Anatomical Therapeutic Chemical/Defined Daily Dose system. Consumption of drugs was expressed as the number of defined daily doses per 1000 inhabitants per day (DDD/1000/day). We examined consumption of the following classes of antibiotics used in the treatment of infections caused by gram-negative bacteria: aminopenicillins, combinations of penicillin/beta-lactamase inhibitors, fluoroquinolones, third-generation cephalosporins (except for ceftazidime) and aminoglycosides (except for amikacin). Consumption of ceftazidime and amikacin is observed separately because their resistance is also monitored independently.

To get more details on antibiotic consumption in hospitals, we conducted a PPS on antibiotic consumption in 3 general hospitals and Clinical Center of Montenegro in 2015, using the Global Point Prevalence Survey method. A web-based application was used for data entry, validation, and reporting, as designed by the University of Antwerp ${ }^{12}$. Data are collected for all patients admitted to hospitals who received some antibiotics on the day of survey. Relevant variables included the type of antibiotic agents, indications for treatment (therapeutic versus prophylactic use) and type of therapy (targeted or empirical).

The rate of AMR at the national level is evaluated based on the susceptibility to antibiotics of invasive strains isolated from blood and cerebrospinal fluid according to Central Asian and European Surveillance of Antimicrobial Resistance (CAESAR) and European Antimicrobial Resistance Surveillance Network (EARS-Net) methodology ${ }^{10,11}$. In the period from 2016 to 2018, the Institute of Public Health collected results of antimicrobial susceptibility testing of $79 \mathrm{~K}$. pneumoniae and $68 \mathrm{E}$. coli isolates from blood in all public microbiological laboratories examining hospital samples ( 7 general hospitals and Clinical Center of Montenegro). There were no isolates from cerebrospinal fluid during the observation period. Antibiotic susceptibility testing was performed by the disk diffusion method, according to the European Committee on Antimicrobial Susceptibility Testing (EUCAST) guidelines ${ }^{13}$. The susceptibility test panel included the following disks: ampicillin, amoxicillin-clavulanic acid, piperacillintazobactam, ceftriaxone, ceftazidime, imipenem, meropenem, gentamicin, amikacin and ciprofloxacin.

\section{Statistical analysis}

Linear regression was used to assess the trend of antibiotic consumption at hospitals in the 2009-2015 period. The model $\mathrm{Y}=\alpha+\beta \mathrm{x}+\varepsilon$, where $\mathrm{x}$ was ordinal number of the current year, $\mathrm{Y}$ was the corresponding consumption of antibiotics, $\alpha$ was the intercept coefficient or constant term, and $\beta$ was the slope coefficient, was used throughout analysis. The slope coefficient represents the quantity of reduction or enlargement in antibiotic consumption per year. We also calculated the corresponding ratio of determination $\mathrm{R}^{2}$. The results 
were expressed as mean and standard deviation (SD) for normally distributed variables or median and interquartile range (IQR) for non-normally distributed variables. The Shapiro-Wilk test was used to test the normality of variable distribution. Statistical analyses were performed using STATISTICA software for trend assessment and IBM SPSS Statistics for Windows, Version 22.0 for other analyses. A value of $\mathrm{p} \leq 0.05$ was considered significant.

\section{Results}

The mean annual antibiotic consumption in Montenegrin hospitals in the period from 2009 to 2015 was

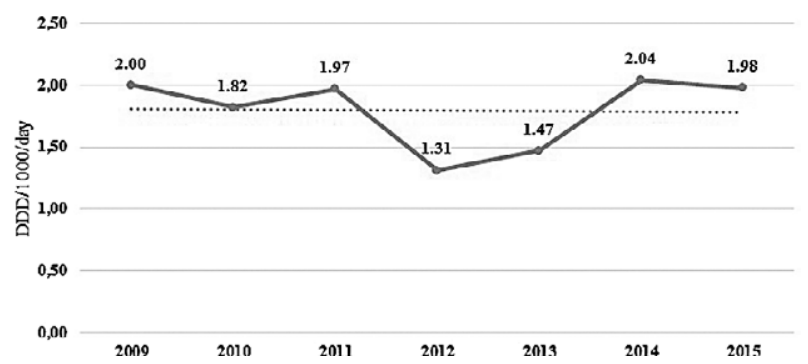

Fig. 1. Inpatient antibiotic consumption in Montenegro 2009-2015 ( $p=0.946)$.
1.8 DDD/1000/day. Although annual antibiotic use varied between the lowest value in 2012 (1.31 DDD/ 1000/day) and the highest value recorded in 2014 (2.04 $\mathrm{DDD} / 1000 /$ day), there was no increasing trend ( $p=0.946)$ observed between 2009 and 2015 (Fig. 1).

Third-generation cephalosporins (except for ceftazidime) were the most commonly used antibiotics in hospitals during the observation period, with median annual consumption of $0.66 \mathrm{DDD} / 1000 /$ day (IQR: $0.58-0.71$ ), followed by fluoroquinolones and aminoglycosides (except for amikacin) with 0.19 $\mathrm{DDD} / 1000 /$ day and $0.17 \mathrm{DDD} / 1000 /$ day, respectively. If we exclude years 2012 and 2013 from the calculation, the period when the consumption of third-generation cephalosporins sharply dropped due to disruption in ceftriaxone supply, these antibiotics were at the leading position and showed a steady increase consumption trend $\left(\mathrm{R}^{2}=0.8456 ; \beta=0.04 ; \mathrm{p}=0.0271\right)$. The use of fluoroquinolones in each individual year varied from the lowest value $(0.16 \mathrm{DDD} / 1000 /$ day $)$ in 2010 to the highest value (2.1 DDD/1000/day) in 2014. In contrast, the lowest aminoglycoside consumption was recorded in 2014 (0.14 DDD/1000/ day) and the highest in 2009 (2.1 DDD/1000/day), but there was no significant linear trend observed in

Table 1. Annual inpatient antibiotic consumption in Montenegro 2009-2015

\begin{tabular}{|c|c|c|c|c|c|c|c|c|}
\hline \multirow[b]{2}{*}{ Antibiotic } & \multicolumn{8}{|c|}{ DDD/1000/day } \\
\hline & 2009 & 2010 & 2011 & 2012 & 2013 & 2014 & 2015 & $\begin{array}{l}\text { Mean } \pm \text { SD/ } \\
\text { median }(\mathrm{IQR})\end{array}$ \\
\hline $\begin{array}{l}\text { Aminopenicillins } \\
\text { (ampicillin+amoxicillin) }\end{array}$ & 0.15 & 0.10 & 0.12 & 0.12 & 0.11 & 0.11 & 0.12 & $0.12 \pm 0.02$ \\
\hline Amoxicillin-clavulanic acid & 0.10 & 0.07 & 0.08 & 0.08 & 0.10 & 0.10 & 0.08 & $0.09 \pm 0.01$ \\
\hline Piperacillin-tazobactam & 0.00 & 0.00 & 0.00 & 0.00 & 0.01 & 0.01 & 0.01 & $0.004 \pm 0.005$ \\
\hline $\begin{array}{l}\text { Third-generation cephalosporins } \\
\text { (ceftriaxone+cefotaxime) }^{* * *}\end{array}$ & 0.56 & 0.61 & 0.70 & $0.06^{*}$ & $0.09^{*}$ & 0.69 & 0.72 & $0.66(0.58-0.71)$ \\
\hline Ceftazidime & 0.05 & 0.04 & 0.02 & 0.04 & 0.04 & 0.04 & 0.02 & $0.04 \pm 0.01$ \\
\hline Carbapenems $s^{* * *}$ & 0.04 & 0.04 & 0.05 & 0.05 & 0.06 & 0.06 & 0.06 & $0.05 \pm 0.01$ \\
\hline $\begin{array}{l}\text { Aminoglycosides } \\
\text { (gentamicin+tobramycin) }\end{array}$ & 0.21 & 0.18 & 0.15 & 0.16 & 0.16 & 0.14 & 0.16 & $0.17 \pm 0.02$ \\
\hline Amikacin & 0.10 & 0.08 & 0.11 & 0.09 & 0.10 & 0.10 & 0.04 & $0.09(0.08-0.10)$ \\
\hline Fluoroquinolones & 0.18 & 0.16 & 0.18 & 0.19 & 0.20 & 0.21 & 0.18 & $0.19 \pm 0.02$ \\
\hline Total & 1.29 & 1.23 & 1.34 & 0.70 & 0.78 & 1.38 & 1.29 & $1.80 \pm 0.29$ \\
\hline
\end{tabular}

$\mathrm{DDD} / 1000 /$ day = number of defined daily doses per 1000 inhabitants per day; SD = standard deviation; IQR = interquartile range; *consumption of third-generation cephalosporins in two years (2012 and 2013) was excluded on calculating mean value due to ceftriaxone supply disruption; ${ }^{* *}$ statistically significant increase in consumption trend ( $\left.\mathrm{p}=0.0271\right) ;{ }^{* * *}$ statistically significant increase in consumption trend $(\mathrm{p}=0.0043)$ 


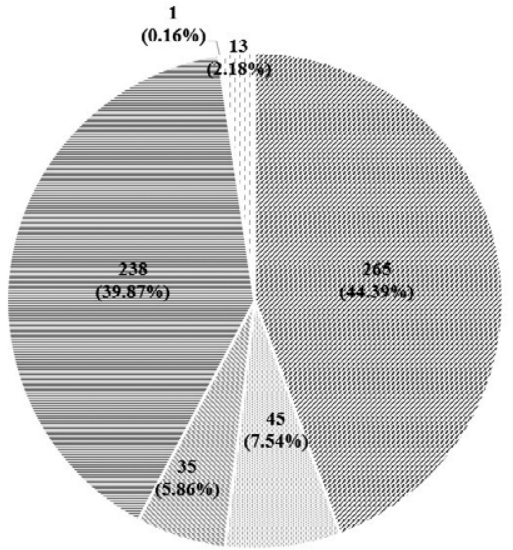

$\begin{array}{ll}\text { "Community acquired infections (CAI) } & \text { Hospital acquired infections (HAI) } \\ \text { "Medical prophylaxis } & \text { Surgical prophylaxis } \\ \text { - Other } & \text { Unknown }\end{array}$

Fig. 2. Inpatient use of antibiotics according to indication (source: Point Prevalence Survey conducted in Montenegro in 2015). the consumption of fluoroquinolones and aminoglycosides during the given time interval. At the same time, carbapenem use increased significantly from 0.04 $\mathrm{DDD} / 1000 /$ day in 2009 to $0.06 \mathrm{DDD} / 1000 /$ day in $2015\left(\mathrm{R}^{2}=0.862 ; \beta=0.0043 ; \mathrm{p}=0.0043\right)$ (Table 1$)$.

A total of 969 patients in Montenegro were included in the PPS on antibiotic consumption in hospitals in 2015. The antimicrobial prevalence rate was $50.8 \%$ (492/969). Out of 597 antibiotics prescribed in hospitals, $51.93 \%$ were used to treat community acquired infections (CAI) and hospital acquired infections (HAI), and $39.87 \%$ were prescribed for surgical prophylaxis (Fig. 2).

Ceftriaxone was the most commonly administered type of antibiotic in general (44.56\%). In the treatment of CAI with $48.68 \%$ and HAI with $31.11 \%$, this antibiotic was followed by ciprofloxacin $(21.89 \%$ and $17.8 \%$, respectively) and metronidazole $(6.42 \%$ and

Table 2. Percentage of antibiotics used for different indications - data from Point Prevalence Survey conducted in Montenegro in 2015

\begin{tabular}{|c|c|c|c|c|c|c|c|c|c|c|c|c|}
\hline \multirow[t]{2}{*}{ Antimicrobial } & \multicolumn{2}{|c|}{$\begin{array}{l}\text { Community- } \\
\text { acquired } \\
\text { infections }\end{array}$} & \multicolumn{2}{|c|}{$\begin{array}{l}\text { Hospital- } \\
\text { acquired } \\
\text { infections }\end{array}$} & \multicolumn{2}{|c|}{$\begin{array}{l}\text { Medical } \\
\text { prophylaxis }\end{array}$} & \multicolumn{2}{|c|}{$\begin{array}{l}\text { Surgical } \\
\text { prophylaxis }\end{array}$} & \multicolumn{2}{|c|}{$\begin{array}{l}\text { Other/ } \\
\text { unknown }\end{array}$} & \multicolumn{2}{|c|}{ Total } \\
\hline & $\mathrm{n}$ & $\%$ & $\mathrm{n}$ & $\%$ & $\mathrm{n}$ & $\%$ & $\mathrm{n}$ & $\%$ & $\mathrm{n}$ & $\%$ & $\mathrm{n}$ & $\%$ \\
\hline Ampicillin/amoxicillin & 6 & 2.26 & 1 & 2.22 & 8 & 22.86 & 9 & 3.78 & 1 & 7.14 & 25 & 4.19 \\
\hline $\begin{array}{l}\text { Amoxicillin/ } \\
\text { clavulanic acid }\end{array}$ & 1 & 0.38 & 0 & 0.00 & 0 & 0.00 & 0 & 0.00 & 0 & 0.00 & 1 & 0.17 \\
\hline Piperacillin/tazobactam & 0 & 0.00 & 1 & 2.22 & 0 & 0.00 & 4 & 1.68 & 0 & 0.00 & 5 & 0.84 \\
\hline Cefazolin & 0 & 0.00 & 0 & 0.00 & 0 & 0.00 & 14 & 5.88 & 0 & 0.00 & 14 & 2.35 \\
\hline Cephalexin & 1 & 0.38 & 0 & 0.00 & 3 & 8.57 & 8 & 3.36 & 0 & 0.00 & 12 & 2.01 \\
\hline Cefprozil & 0 & 0.00 & 0 & 0.00 & 0 & 0.00 & 3 & 1.26 & 0 & 0.00 & 3 & 0.50 \\
\hline Cefixime & 5 & 1.89 & 2 & 4.44 & 1 & 2.86 & 13 & 5.46 & 0 & 0.00 & 21 & 3.52 \\
\hline Ceftriaxone & 129 & 48.68 & 14 & 31.11 & 9 & 25.71 & 109 & 45.8 & 5 & 35.71 & 266 & 44.56 \\
\hline Ceftazidime & 4 & 1.51 & 1 & 2.22 & 1 & 2.86 & 2 & 0.84 & 1 & 7.14 & 9 & 1.51 \\
\hline Imipenem/meropenem & 8 & 3.02 & 4 & 8.89 & 1 & 2.86 & 4 & 1.68 & 3 & 21.43 & 20 & 3.35 \\
\hline Gentamicin & 8 & 3.02 & 3 & 6.67 & 5 & 14.29 & 27 & 11.34 & 0 & 0.00 & 43 & 7.20 \\
\hline Amikacin & 4 & 1.51 & 0 & 0.00 & 3 & 8.57 & 6 & 2.52 & 0 & 0.00 & 13 & 2.18 \\
\hline Ciprofloxacin & 58 & 21.89 & 8 & 17.78 & 1 & 2.86 & 12 & 5.04 & 1 & 7.14 & 80 & 13.40 \\
\hline Azithromycin/erythromycin & 6 & 2.26 & 1 & 2.22 & 0 & 0.00 & 3 & 1.26 & 0 & 0.00 & 10 & 1.68 \\
\hline Doxycycline & 7 & 2.64 & 0 & 0.00 & 0 & 0.00 & 0 & 0.00 & 0 & 0.00 & 7 & 1.17 \\
\hline $\begin{array}{l}\text { Trimethoprim/ } \\
\text { sulfamethoxazole }\end{array}$ & 2 & 0.75 & 2 & 4.44 & 2 & 5.71 & 0 & 0.00 & 0 & 0.00 & 6 & 1.01 \\
\hline Metronidazole & 17 & 6.42 & 4 & 8.89 & 1 & 2.86 & 16 & 6.72 & 2 & 14.29 & 40 & 6.70 \\
\hline Vancomycin & 7 & 2.64 & 1 & 2.22 & 0 & 0.00 & 1 & 0.42 & 0 & 0.00 & 9 & 1.51 \\
\hline Other & 2 & 0.75 & 3 & 6.67 & 0 & 0.00 & 7 & 2.94 & 1 & 7.14 & 13 & 2.18 \\
\hline
\end{tabular}


$8.89 \%$, respectively); with $25.71 \%$ in medical prophylaxis, it was followed by aminopenicillins $(22.86 \%)$ and gentamicin (14.29\%); and with $45.8 \%$ for surgical prophylaxis, it was followed by gentamicin (11.34\%) and metronidazole (6.72\%) (Table 2).

Regarding the type of therapy, only $4.75 \%$ of antibiotics for CAI and $11.54 \%$ of antibiotics for HAI were prescribed as targeted treatment (Fig. 3).

Data on antibiotic susceptibility testing of $79 \mathrm{~K}$. pneumoniae and $68 \mathrm{E}$. coli isolates were collected from 2016 to 2018 , which was $35.68 \%$ of 412 isolated bacteria from positive blood cultures. A total of 10959

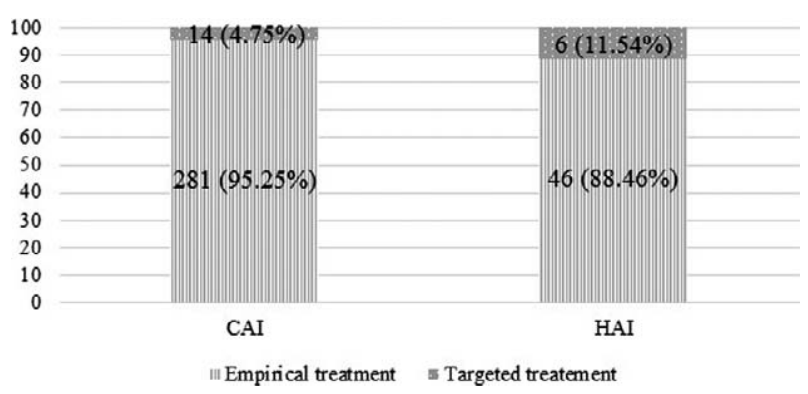

Fig. 3. Antibiotic use according to type of treatment and indications (source: Point Prevalence Survey conducted in Montenegro in 2015).

$\mathrm{CAI}=$ community acquired infections; $\mathrm{HAI}=$ hospital acquired infections

Table 3. Time of sampling positive blood cultures in Montenegrin hospitals 2016-2018

\begin{tabular}{|l|l|l|}
\hline Days from hospital & \multicolumn{2}{|l|}{ Positive blood culture, $\mathrm{n}(\%)$} \\
\cline { 2 - 3 } $\begin{array}{l}\text { admission } \\
\text { to blood culture } \\
\text { sampling }\end{array}$ & $\begin{array}{l}\text { Klebsiella } \\
\text { pneumoniae }\end{array}$ & $\begin{array}{l}\text { Escherichia } \\
\text { coli }\end{array}$ \\
\hline $\begin{array}{l}\leq 2 \text { days } \\
>2 \text { days }\end{array}$ & $9(11.4 \%)$ & $42(61.8 \%)$ \\
\hline Total & $70(88.6 \%)$ & $26(38.2 \%)$ \\
\hline
\end{tabular}

blood samples were tested per 238681 patients admitted, yielding 45.8 blood cultures per 1000 admissions.

A total of $88.6 \%$ and $38.2 \%$ of positive blood cultures with $K$. pneumoniae and E. coli isolates, respectively, were sampled after more than two days of $\mathrm{pa}^{-}$ tient hospital stay (Table 3).

The median time elapsed from hospitalization to sampling of blood culture that gave a positive result with $K$. pneumoniae or $E$. coli isolates was ten days (IQR: 5.25-21.50) and one day (IQR: 1.00-6.00), respectively (Table 4).

The resistance rate of $K$. pneumoniae was highest to ceftriaxone/cefotaxime, followed by ceftazidime and gentamicin $(93.59 \%, 90.79 \%$ and $89.87 \%$, respectively). The resistance rate to carbapenems (imipenem/meropenem) was $7.69 \%$. Out of 79 isolates, multidrug resistance was $60.26 \%$. When annual data were analyzed, a total of 28, 29 and 22 isolates of $K$. pneumoniae were collected in 2016, 2017 and 2018, respectively. $K$. pneumoniae showed the highest resistance rate to ceftriaxone/cefotaxime in 2016, 2017 and 2018 (89\%, $97 \%$ and $95 \%$, respectively) individually, as well as for the observation period as a whole. A similar rate of resistance was observed for ceftazidime ( $85 \%, 96 \%$ and $91 \%$, respectively), amoxicillin/clavulanic acid (85\%, $86 \%$ and $91 \%$, respectively) and gentamicin $(82 \%, 97 \%$ and $91 \%$, respectively). High rates of resistance $(\geq 50 \%)$, annually in 2016, 2017 and 2018, were reported for all antibiotics tested except for amikacin $(22 \%, 41 \%$ and $5 \%$, respectively) and carbapenems $(4 \%, 14 \%$ and $5 \%$, respectively). For $E$. coli, the total resistance rate was $89.06 \%$ to ampicillin/amoxicillin, $70.15 \%$ to ceftriaxone and $61.54 \%$ to ceftazidime. There was not any isolate resistant to carbapenems. Multidrug resistance was $22.73 \%$. According to data analyzed by years, in 2016, 2017 and 2018, a total of 19, 20 and 29 invasive isolates of $E$. coli were collected, respectively. E. coli isolates were most frequently resistant to ampicillin/

Table 4. Time elapsed from hospitalization to sampling of positive blood cultures in Montenegrin hospitals (2016-2018)

\begin{tabular}{|l|l|l|l|}
\hline \multirow{2}{*}{ Isolated bacterium } & \multicolumn{3}{|c|}{$\begin{array}{c}\text { Time elapsed from admission to sampling of blood culture } \\
\text { with positive result (days) }\end{array}$} \\
\cline { 2 - 4 } & Median (interquartile range) & Minimum & Maximum \\
\hline Klebsiella pneumoniae & $10(5.25-21.50)$ & 0 & 108 \\
Escherichia coli & $1.00(1.00-6.00)$ & 0 & 53 \\
Total & $5(1-14)$ & 0 & 114 \\
\hline
\end{tabular}




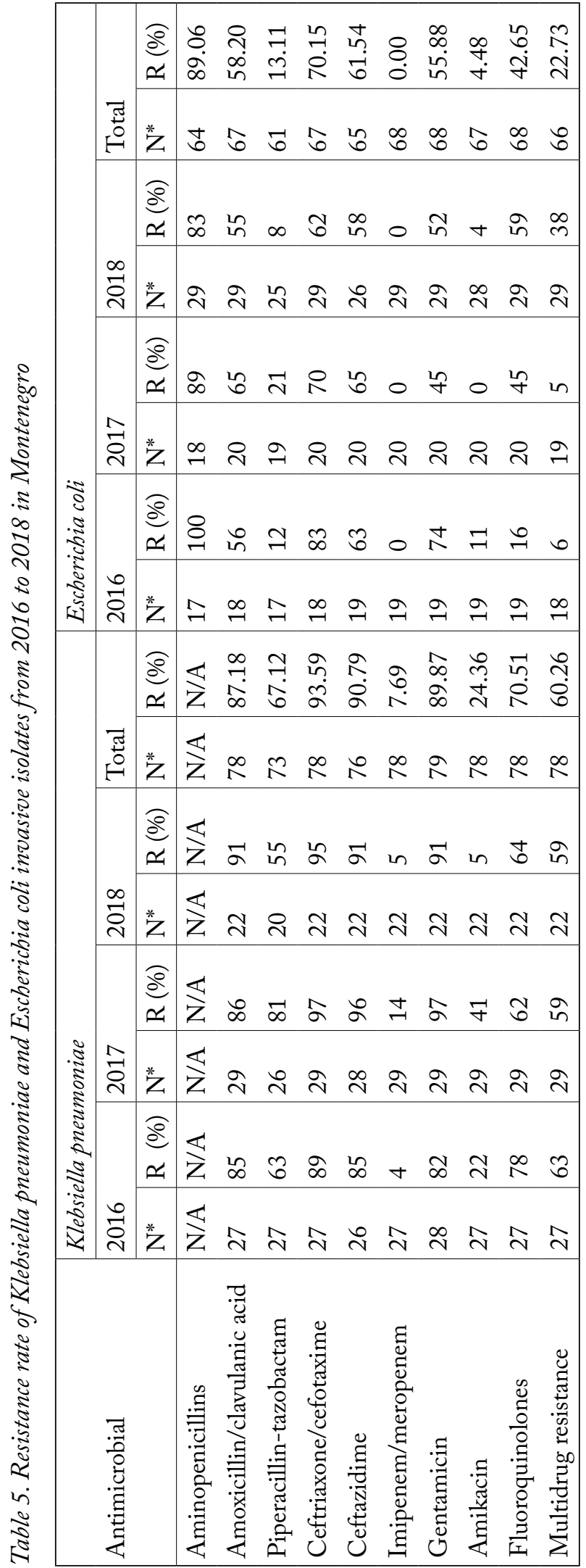

amoxicillin (100\%, 89\% and 83\%, respectively). Similar to $K$. pneumoniae, E. coli also showed a high rate of resistance to ceftriaxone/cefotaxime $(83 \%, 70 \%$ and $62 \%$, respectively), ceftazidime $(63 \%, 65 \%$ and $58 \%$, respectively) and gentamicin (74\%, $45 \%$ and $52 \%$, respectively). Resistance rates lower than $50 \%$ for each year were individually recorded only for amikacin, piperacillin-tazobactam and carbapenems. While the percentage of multidrug-resistant $K$. pneumoniae strains ranged between $59 \%$ and $63 \%$, multidrug-resistant $E$. coli strains ranged between $5 \%$ and $38 \%$ in the observed period. According to the results, the percentage of $E$. coli resistant to ampicillin/amoxicillin and ceftriaxone/cefotaxime decreased from 2016 to 2018 (from $100 \%$ to $83 \%$ and from $83 \%$ to $62 \%$, respectively), and to fluoroquinolones it increased from $16 \%$ to $59 \%$ (Table 5).

Despite the changes observed, the trends in resistance rate to each antibiotic of both bacteria examined could not be statistically analyzed due to the short observation period (only three years). Besides, the significance of annual changes in the rate of resistance of both bacteria to each of the antibiotics during the observation period (2016-2018) could not be demonstrated due to the small number of isolates per year $(n<30)$.

\section{Discussion}

Many factors are potent drivers of antibiotic resistance, and the main driver is the overuse of antibiotics, which also includes inappropriate use (inappropriate choices, inadequate dosing, poor adherence to treatment guidelines ${ }^{14}$. Analyzing data on antibiotic consumption, prescribing habits of doctors and antibiotic resistance has enabled identification of the weak points in the use of antibiotics ${ }^{3}$.

Concerning the quantity of antibiotics used in Montenegrin hospitals in the 2009-2015 period, with a mean value of $1.8 \mathrm{DDD} / 1000 /$ day, the country was at the level of the European mean, which ranged from 1.84 to $2 \mathrm{DDD} / 1000 /$ day from 2010 to 2014 , respectively $^{15}$. In general terms, antibiotics were not consumed excessively in Montenegrin hospitals compared to European mean, but antibiotic consumption can still be more rational.

Even at not too high overall consumption levels, however, antibiotics may be misused. If the relative 
consumption of different antibiotics is analyzed, then the data show the use of third-generation cephalosporins to predominate the antibiotic use in hospitals in Montenegro. The highest consumption in the observed period was recorded in 2015, when it was more than two times higher than the European mean for that year (0.34 DDD/1000/day). Only two years with obstacles in procurement of third-generation cephalosporins (especially ceftriaxone) led to an enormous fall in overall hospital consumption of antibiotics in Montenegro. The highest fluoroquinolone consumption was recorded in 2014, but even then it was slightly below the European Union/European Economic Area (EU/EEA) countries mean $(0.23 \mathrm{DDD} / 1000 / \text { day })^{17}$. Although consumption of aminoglycosides (without amikacin) was declining, even the lowest value recorded in 2014 was two and more times higher than the mean consumption in EU/EEA countries for that year (0.06 DDD/1000/day), especially if it is taken into consideration that the consumption of aminoglycosides has not been monitored separately by the European Surveillance of Antimicrobial Consumption (ESAC) network, but together with amphenicols and combined antibiotics ${ }^{15}$. Carbapenem consumption in Montenegro was close to the annual mean consumption in EU/EEA countries, which was $5.54 \mathrm{DDD} /$ 1000/day between 2011 and 2015, however, worrying is the significantly increasing trend of carbapenem consumption, as these are reserve antibiotics used in the treatment of serious infections caused by multidrug-resistant gram-negative bacteria ${ }^{16}$.

Data indicate overuse of third-generation cephalosporins (ceftriaxone/cefotaxime) and aminoglycosides (gentamicin/tobramycin) in hospitals in Montenegro relative to EU/EEA countries and an increasing trend of third-generation cephalosporin and carbapenem consumption. Numerous studies confirm the association between the growing use of antibiotics and rising antibiotic resistance ${ }^{9,18}$. Development of carbapenem resistance is of particular concern because carbapenem-resistant bacteria are highly drug-resistant, and only a few antibacterial groups such as polymyxins are available for the treatment of patients infected with such bacteria ${ }^{19}$.

The PPS indicated the need to rationalize the use of antibiotics in hospitals, as the percentage of patients receiving antibiotics on the day of the study in Montenegro was higher than the European mean $(50.5 \%$ vs.
$31.9 \%)^{3}$. In addition, out of all antibiotics prescribed in hospitals on the day of the study, the percentage of antibiotics used for surgical prophylaxis was 2.6 times higher than the European mean of approximately $15 \%{ }^{20}$. The misuse of antibiotics is reflected in the fact that ceftriaxone is the most frequently used antibiotic in hospitals in Montenegro, not only in the treatment of infections but also for prophylaxis. Although in 2014, the Ministry of Health published guidelines for the implementation of antibiotic prophylaxis in surgery $^{21}$, where it is determined that the use of thirdgeneration cephalosporins is not recommended, the results of the study conducted in 2015 showed that ceftriaxone made almost half of antibiotics used for prophylactic purposes in surgery. Cefazolin, which is a drug of choice for antibiotic prophylaxis for all clean and most clean-contaminated surgical procedures according to national guidelines ${ }^{21}$, was almost unused in hospitals in Montenegro and it accounted for $5.88 \%$ of all antibiotics used in surgical prophylaxis. According to the PPS data, targeted therapy was very rarely applied in the hospitals in Montenegro. Targeted therapy for the treatment of CAI in Montenegro was almost five times less frequent than in European hospitals $(4.75 \% \text { vs. } 23.1 \%)^{3}$.

The lack of national AMR data (Montenegro started to collect national AMR data in 2016) and insufficient use of microbiological analyses in detecting the cause of infections could be the reasons why ceftriaxone is the most commonly used antibiotic in treating CAI and HAI. Empirical treatment of infections in conditions where there are no national data on resistance and national guidelines significantly compromises therapeutic success, contributes to the overuse of antibiotics, and increases the risk of developing and rising resistance. The usage of antibiotics with a broad spectrum of activity is a risk factor for colonization with resistant strains of enterobacteria and their spread in the population.

In general, resistance may be overestimated. Namely, the number of blood cultures of 45.8/1000 admitted patients was by far below the European mean, which, according to literature data, is 255/1000 admissions for EU member states and 192/1000 admissions in European countries that are not EU members ${ }^{22}$. These data suggest that blood cultures are rarely used for diagnostic purposes in Montenegro. The median time elapsed from hospitalization to blood sampling for 
blood cultures with positive results where $K$. pneumonia was isolated was ten days, confirming that this analysis is usually done after failure of therapies or after worsening of patient condition. Additionally, a very high percentage of blood cultures with isolated $K$. pneumoniae was taken after more than two days of hospital stay. Therefore, our data may indicate the resistance patterns present in clinical settings in the country. Thus, data must be interpreted with caution and should not necessarily be considered generalizable to patients with invasive infections, especially patients with CAI. Based on the above, it is clear that improvement of resistance data requires advancement of good clinical practice by increasing the number of blood cultures taken for diagnostic purposes.

Bearing in mind the overuse of broad-spectrum antibiotics in hospitals in Montenegro, the results on the resistance rate of examined pathogens are not surprising. When analyzing the resistance data, we noticed that isolated strains of $K$. pneumonia showed the highest rate of resistance to third-generation cephalosporins (ceftriaxone/cefotaxime and ceftazidime) and aminoglycosides (except for amikacin). Resistance to third-generation cephalosporins shown by $K$. pneumoniae strains collected over a three-year period is among highest in Europe if data from EU/EEA countries are considered, where, according to the results published for 2018, the population-weighted mean of resistance to the group of this antibiotic was $31.7 \%$. In 2018 , the highest resistance rate of $77.7 \%$ was recorded in Bulgaria ${ }^{23}$. According to the latest data from the WHO for 2018, the resistance rate of $K$. pneumoniae to third-generation cephalosporins in Montenegro is higher in comparison with data collected in some surrounding countries (Bosnia and Herzegovina $71 \%$ and Serbia 85\%) and similar to Northern Macedonia $(95 \%)^{24}$. It is known that reduced use of a particular antibiotic can recover sensitivity to it. In Croatia, reduced use of amoxicillin/clavulanic acid as the choice of treatment for upper respiratory tract/urinary tract infections decreased its resistance rate, still, such an effect requires many years of reduction in the use of antibiotics $^{25}$. In Montenegro, an additional disadvantage is that usage of third-generation cephalosporins in hospitals has an unfavorable growing trend. Aminoglycoside resistance differs significantly when gentamicin and amikacin are considered separately. Tobramycin is only marginally used in hospitals in Monte- negro, but when it comes to resistance to aminoglycosides, it is actually about the resistance to gentamicin because the consumption and resistance to amikacin have been monitored separately. The overall gentamicin resistance rate over the three-year period was higher than amikacin resistance, as the mean annual gentamicin consumption in that period was by far higher than the amikacin consumption. The data illustrated the relationship between high consumption of thirdgeneration cephalosporins (ceftriaxone/cefotaxime) and gentamicin, and high levels of resistance of $K$. pneumoniae to these antibiotics. Even though the mean annual consumption of fluoroquinolones during the observed period was slightly lower than the European mean, in the period from 2016 to 2018, the resistance rate of $K$. pneumoniae to fluoroquinolones was twice higher in Montenegro compared to the mean values recorded in EU/EEA countries of 30.3\%, 31.5\% and $31.6 \%$, respectively ${ }^{23}$. Unlike third-generation cephalosporins, which in outpatient settings can only be used as an extension of hospital treatment, the use of fluoroquinolones has no limitations, which could be an additional selective pressure of this class of antibiotics. Analysis of outpatient consumption might contribute to explaining the high rate of resistance to fluoroquinolones. A high rate of resistance to fluoroquinolones is recorded in the surrounding countries, i.e. Northern Macedonia (87\%), Serbia (73\%) and Bosnia and Herzegovina (59\%) in $2018^{23}$, as well as in some EU/EEA Balkan Peninsula countries (Bulgaria 62.7\% and Greece 68.1\%) ${ }^{24}$. Although Bulgaria and Greece recorded high rates of resistance to fluoroquinolones, these countries did not have a high consumption of fluoroquinolones in previous years. In Bulgaria, consumption in 2014 and 2015 was slightly lower than the European mean (0.16 DDD/1000/day for both years), whereas in Greece it was somewhat above the European mean (0.27 DDD/1000/day and 0.31 DDD/ $1000 /$ day, respectively $)^{17}$. In a study conducted in 2014 , Sedlakova et al. also indicated an increase in resistance to fluoroquinolones despite the lower use of these antibiotics and concluded that selection pressure might not be an explanation for the increasing prevalence of fluoroquinolone-resistant Enterobacteriaceae ${ }^{26}$. It can be assumed that the relationship between resistance and fluoroquinolone administration is probably also determined by some additional factors that need to be explored. The growing trend of carbapenem consump- 
tion in the 2009-2015 period resulted in the emergence of carbapenem resistance in 2017 and 2018. The second Joint Interagency Antimicrobial Consumption and Resistance Analysis report from ECDC, the European Food Safety Authority and the European Medicines Agency showed a strong association between carbapenem consumption and the percentage of carbapenem-resistant invasive $K$. pneumoniae isolates in EU/EEA countries reporting these data ${ }^{18}$. Carbapenem resistance was almost always combined with resistance to several other key antibiotic groups, severely limiting treatment options for infections caused by these types of bacteria ${ }^{27}$.

Out of all antibiotics tested from 2016 to 2018, isolated $E$. coli showed the highest rate of resistance to aminopenicillins, by far higher than the European mean of $58.7 \%, 58.2 \%$ and $58.3 \%$, respectively ${ }^{23,28,29}$. The mean annual consumption of aminopenicillins in hospitals in Montenegro during a seven-year period was quite uniform and was not too high. With a similar yearly mean hospital consumption of aminopenicillins of $0.1 \mathrm{DDD} / 1000 /$ day in the period from 2009 to 2014, The Netherlands had an almost twice lower rate of $E$. coli resistance to aminopenicillins in 2016, 2017 and 2018 (45.9\%, 45.9\% and 45.6\%, respectively ${ }^{23,30}$. The explanation for such a high rate of resistance concerning the low consumption of aminopenicillin in Montenegro can be found in the selective pressure of third-generation cephalosporins, which contributed to favoring extended broad-spectrum beta-lactamase producing strains of $E$. coli, as indicated by the high rate of resistance to all beta-lactam antibiotics (except for carbapenem), and so to aminopenicillins. Resistance percentages were generally lower in $E$. coli than in $K$. pneumonia to all antibiotics tested, but $E$. coli still showed a high resistance rate (over $40 \%$ ) to all tested antibiotics except for piperacillin/tazobactam, amikacin and carbapenems. Among E. coli isolates, there were no strains resistant to carbapenems. Carbapenem resistance has remained rare in E. coli throughout Europe ${ }^{31}$. However, constant monitoring of resistance to carbapenems is still necessary because E. coli strains resistant to carbapenems, as well as other enterobacteria, are well adapted and easy to spread both in hospital and outpatient environments ${ }^{29}$.

A particular problem for clinicians in the choice of therapy is posed by multidrug-resistant strains. In 2016, 2017 and 2018, there were almost three times higher percentages of multidrug-resistant $K$. pneumoniae than the European mean for the same period $(20.6 \%, 20.5 \%$ and $19.6 \%$, respectively). Similarly, in 2018 , the percentage of multidrug-resistant strains of E. coli in Montenegro was by far above the EU/EEA country mean of $6.2 \%{ }^{23}$.

\section{Conclusion}

The results of this study identified a disturbing increase in the consumption of third-generation cephalosporins and carbapenems, as well as the association of high consumption of third-generation cephalosporins and aminoglycosides (except for amikacin) with a high rate of $K$. pneumoniae and $E$. coli resistance to these drugs in Montenegrin hospitals. Montenegrin doctors' prescribing practices indicated abuse of ceftriaxone both for therapeutic and prophylactic purposes. The case may be due to the inadequate use of microbiological analyses, insufficient blood culture sampling for diagnostic purposes, the lack of specific national guidelines, and failure to comply with the existing ones. This study reflects the fact that it is necessary to create and introduce an antimicrobial stewardship program in Montenegrin hospitals and continue to monitor antibiotic consumption, prescribing habits and antibiotic resistance.

\section{References}

1. Toner E, Adalja A, Gronvall GK, Cicero A, Inglesby TV. Antimicrobial resistance is a global health emergency. Health Secur. 2015;13(3):153-5. doi: 10.1089/hs.2014.0088

2. Van Boeckel TP, Gandra S, Ashok A, Caudron Q, Grenfell BT, Levin SA, Laxminarayan R. Global antibiotic consumption 2000 to 2010: an analysis of national pharmaceutical sales data. Lancet Infect Dis. 2014;14:742-50. doi: 10.1016/S14733099(14)70780-7

3. Versporten A, Zarb P, Caniaux I, Gros MF, Drapier N, Miller M, Jarlier V, Nathwani D, Goossens H, on behalf of the Global-PPS network. Antimicrobial consumption and resistance in adult hospital inpatients in 53 countries: results of an internetbased global point prevalence survey. Lancet Glob Health. 2018;6(6):e619-e629. doi: 10.1016/S2214-109X(18)30186-4

4. Kritsotakis EI, Gikas A. Surveillance of antibiotic use in hospitals: methods, trends and targets. Clin Microbiol Infect. 2006; 12(8):701-4. doi:10.1111/j.1469-0691.2006.01415.x

5. Štefkovičová M, Litvová S, Meluš V, Krištúfková Z, Bražinová A. Point prevalence study of antimicrobial usage in acute care hospitals in the Slovak Republic. J Hosp Infect. 2016;93(4): 403-9. doi: 10.1016/j.jhin.2016.02.017 
6. Exner M, Bhattacharya S, Christiansen B, et al. Antibiotic resistance: what is so special about multidrug-resistant gramnegative bacteria? GMS Hyg Infect Control. 2017;12:Doc05. doi:10.3205/dgkh000290

7. De Angelis G, D'Inzeo T, Fiori B, Spanu T, Sganga G. Burden of antibiotic resistant gram negative bacterial infections: evidence and limits. J Med Microb Diagn. 2014;3:1. doi: 10.4172/ 2161-0703.1000132

8. de Kraker ME, Davey PG, Grundmann H, BURDEN study group. Mortality and hospital stay associated with resistant Staphylococcus aureus and Escherichia coli bacteremia: estimating the burden of antibiotic resistance in Europe. PLoS Med. 2011;8(10):e1001104. doi: 10.1371/journal.pmed.1001104

9. Cusini A, Herren D, Bütikofer L, Plüss-Suard C, Kronenberg A, Marschall J. Intra-hospital differences in antibiotic use correlate with antimicrobial resistance rate in Escherichia coli and Klebsiella pneumoniae: a retrospective observational study. Antimicrob Resist Infect Control. 2018;7:89. doi: 10.1186/s13756018-0387-0

10. WHO. Central Asian and European Surveillance of Antimicrobial Resistance. CAESAR Manual Version 3, 2019.

11. European Antimicrobial Resistance Surveillance Network (EARS-Net). Antimicrobial resistance (AMR) reporting protocol 2020.

12. Versporten A, Drapier N, Zarb P, Caniaux I, Gros MF, Miller M, Jarlier V, Nathwani D, Goossens H. The Global Point Prevalence Survey of Antimicrobial Consumption and Resistance (Global-PPS): A Worldwide Antimicrobial Web-Based Point Prevalence Survey. Open Forum Infect Dis. 2015;2(1). doi. org/10.1093/ofid/ofv133.25

13. Matuschek E, Brown DFJ, Kahlmeter G. Development of the EUCAST disk diffusion antimicrobial susceptibility testing method and its implementation in routine microbiology laboratories. Clin Microbiol Infect. 2014;20(4):O255-66. doi: 10.1111/1469-0691.12373

14. Prestinaci F, Pezzotti P, Pantosti A. Antimicrobial resistance: a global multifaceted phenomenon. Pathog Glob Health. 2015; 109(7):309-18. doi: 10.1179/2047773215Y.0000000030

15. European Centre for Disease Prevention and Control. Antimicrobial consumption. In: ECDC. Annual epidemiological report for 2014. Stockholm: ECDC; 2018.

16. European Centre for Disease Prevention and Control. Antimicrobial consumption 2015. In: ECDC. Annual epidemiological report for 2015. Stockholm: ECDC; 2018.

17. European Centre for Disease Prevention and Control. Surveillance of antimicrobial consumption in Europe, 2013-2014. Stockholm: ECDC; 2018.

18. ECDC (European Centre for Disease Prevention and Control), EFSA (European Food Safety Authority), and EMA (European Medicines Agency), 2017. ECDC/EFSA/EMA second joint report on the integrated analysis of the consumption of antimicrobial agents and occurrence of antimicrobial resistance in bacteria from humans and food-producing animals - Joint Interagency Antimicrobial Consumption and Re- sistance Analysis (JIACRA) Report. EFSA J. 2017;15(7):4872, 135 pp. doi: 10.2903/j.efsa.2017.4872

19. Magiorakos AP, Burns K, Rodriguez Bano J, Borg M, Daikos $\mathrm{G}$, Dumpis $\mathrm{U}$, et al. Infection prevention and control measures and tools for the prevention of entry of carbapenem-resistant Enterobacteriaceae into healthcare settings: guidance from the European Centre for Disease Prevention and Control. Antimicrob Resist Infect Control. 2017;6:113. doi: 10.1186/s13756017-0259-z

20. Ansari F, Erntell M, Goossens H, Davey P. The European surveillance of antimicrobial consumption (ESAC) point-prevalence survey of antibacterial use in 20 European hospitals in 2006. Clin Infect Dis. 2009;49(10):1496-504. doi: 10.1086/ 644617

21. Simovic S, et al. Antimikrobna profilaksa u hirurgiji. Ministry of Health of Montenegro, 2014. http://www.mzdravlja.gov. $\mathrm{me} / \mathrm{rubrike/nacionalne-smjernice} \mathrm{(in} \mathrm{Montenegrin)}$

22. Bouza E, Perez-Molina J, Muñoz P, et al. Bloodstream infections in Europe. Report of ESGNI-001 and ESGNI-002 studies. Clin Microbial Infect. 1999;5:2S1-2S12.

23. European Centre for Disease Prevention and Control. Surveillance of antimicrobial resistance in Europe 2018. Stockholm: ECDC; 2019.

24. WHO Regional Office for Europe. Central Asian and European Surveillance of Antimicrobial Resistance. Annual Report, 2019.

25. Milošević D, Batinić D, Trkulja V, Tambić Andrašević A, Filipović Grčić B, Vrljičak K, Nogalo B, Turudić D, Spajić M. Rational therapy of urinary tract infections in children in Croatia. Acta Clin Croat. 2016;55:428-39. doi: 10.20471/ acc.2016.55.03

26. Sedláková MH, Urbánek K, Vojtová V, et al. Antibiotic consumption and its influence on the resistance in Enterobacteriaceae. BMC Res Notes. 2014;7:454. https://doi.org/10.1186/ 1756-0500-7-454

27. Albiger B, Glasner C, Struelens MJ, Grundmann H, Monnet DL; European Survey of Carbapenemase-Producing Enterobacteriaceae (EuSCAPE) working group. Carbapenemaseproducing Enterobacteriaceae in Europe: assessment by national experts from 38 countries, May 2015. Euro Surveill. 2015; 20(45). doi: 10.2807/1560-7917.ES.2015.20.45.30062

28. European Centre for Disease Prevention and Control. Surveillance of antimicrobial resistance in Europe 2016. Annual Report of the European Antimicrobial Resistance Surveillance Network (EARS-Net). Stockholm: ECDC; 2017.

29. European Centre for Disease Prevention and Control. Surveillance of antimicrobial resistance in Europe - Annual Report of the European Antimicrobial Resistance Surveillance Network (EARS-Net) 2017. Stockholm: ECDC; 2018.

30. SWAB. NethMap 2018. Consumption of antimicrobial agents and antimicrobial resistance among medically important bacteria in The Netherlands in 2017.www.swab.nl.

31. European Centre for Disease Prevention and Control. Rapid risk assessment: carbapenem-resistant Enterobacteriaceae first update 4 June 2018. Stockholm: ECDC; 2018. 


\title{
Sažetak \\ POTROŠNJA ANTIBIOTIKA U BOLNICAMA I STOPA OTPORNOSTI BAKTERIJA KLEBSIELLA PNEUMONIAE I ESCHERICHIA COLI U CRNOJ GORI
}

\author{
G. Mijović, L. Čizmović, M. Nedović Vuković, S. Stamatović i M. Lopičić
}

Neodgovarajuća upotreba antibiotika dovodi do povećanja otpornosti na antibiotike. Infekcije uzrokovane gram-negativnim bakterijama otpornima na antibiotike ozbiljna su prijetnja javnom zdravlju. Ovo istraživanje imalo je za cilj usporediti podatke o potrošnji antibiotika u bolnicama sa stopom antimikrobne rezistentnosti (AMR) invazivnih sojeva Klebsiella pneumoniae i Escherichia coli u Crnoj Gori i osigurati ciljeve za poboljšanje upotrebe antibiotika. Rabili smo nacionalne podatke o potrošnji antibiotika od 2009. do 2015. godine, podatke iz studije presjeka o potrošnji antibiotika u bolnicama u 2015. godini i nacionalne podatke AMR za 79 izolata Klebsiella pneumoniae i 68 izolata Escherichia coli prikupljena iz 8 bolnica od 2016. do 2018. godine. Najčešće primijenjeni antibiotici bili su cefalosporini treće generacije s medijanom godišnje potrošnje od 0,66 DDD/1000/dan. Ceftriakson je najčešće propisivani antibiotik u liječenju izvanbolničkih i bolničkih infekcija te u kirurškoj/medicinskoj profilaksi. Stopa otpornosti Klebsiella pneumoniae bila je najviša na ceftriakson, ceftazidim i gentamicin (93,59\%, 90,79\% odnosno 89,87\%), a Escherichia coli na aminopeniciline, ceftriakson i ceftazidim (89,06\%, $70,15 \%$ odnosno 61,54\%). Visoka potrošnja antibiotika širokog spektra u Crnoj Gori praćena je visokom stopom otpornosti Klebsiella pneumoniae i Escherichia coli na njih. Zlouporaba antibiotika zahtijeva uvođenje programa antimikrobnog upravljanja u crnogorskim bolnicama.

Ključne riječi: Antibiotici, potrošnja; Antibiotici, otpornost; Klebsiella pneumoniae; Escherichia coli; Crna Gora 